\title{
DNA Damage and Oxidative Stress in Patients with Chronic Obstructive Pulmonary Disease
}

\author{
Andréa Lúcia G da Silva ${ }^{\mathrm{a}, \mathrm{b}^{*}}$, Helen T da Rosa ${ }^{\mathrm{c}}$, Clara F Charlier ${ }^{\mathrm{b}}$, Miriam Salvador ${ }^{\mathrm{d}}$, Dinara J \\ Moura $^{\mathrm{e}, \mathrm{f}}$, Andreia R de Moura Valim ${ }^{\mathrm{e}}$, Temenouga N Guecheva ${ }^{\mathrm{b}, \mathrm{g}}$ and João Antônio Pegas \\ Henriques $^{\mathrm{b}, \mathrm{d}, \mathrm{g}}$
}

\author{
${ }^{a}$ Department of Health and Physical Education, University of Santa Cruz do Sul - UNISC, Santa Cruz do Sul/RS, Brazil \\ ${ }^{b}$ Cellular and Molecular Biology Program, Federal University of Rio Grande do Sul - UFRGS, Porto Alegre/RS, Brazil \\ ${ }^{c}$ Scientific Initiation of University of Santa Cruz do Sul - UNISC, Santa Cruz do Sul/RS, Brazil \\ ${ }^{d}$ Institute of Biotechnology, University of Caxias do Sul, Caxias do Sul/RS, Brazil \\ ${ }^{e}$ Department of Biology and Pharmacy, University of Santa Cruz do Sul - UNISC, Santa Cruz do Sul/RS, Brazil \\ ${ }^{f}$ Laboratory of Genetic Toxicology - Federal University of Health Sciences of Porto Alegre - UFCSPA, Porto Alegre/RS, \\ Brazil \\ ${ }^{g}$ Department of Biophysics, Federal University of Rio Grande do Sul-UFRGS, Porto Alegre/RS, Brazil
}

\begin{abstract}
Background: We aimed to assess the level of DNA damage and susceptibility to exogenous mutagens in peripheral blood cells of Chronic Obstructive Pulmonary Disease (COPD) patients and healthy individuals by comet assay. Oxidative stress was also evaluated by means of thiobarbituric acid reactive species (TBARS) in blood plasma.

Methods: Case-control study enrolling 51 COPD patients and 51 controls. Peripheral blood was used to perform the alkaline $(\mathrm{pH}>13)$ and neutral $(\mathrm{pH}=8.5)$ comet assay. For the assessment of susceptibility to exogenous DNA damage, the cells were treated with methylmethane sulfonate (MMS) for 1-hour or 3-hour at $37^{\circ} \mathrm{C}$. The percentage of residual DNA damage after 3-h MMS treatment was calculated using the value of 1-h MMS treatment for each subject as $100 \%$. Lipid peroxidation was evaluated by measuring TBARS in blood plasma.

Results: DNA damage in patients was significantly higher than in controls as measured by the neutral and alkaline comet assay. Residual DNA damage detected after MMS treatment increased in patients, in contrast to controls, indicating higher susceptibility to alkylation damage and/or repair inhibition. High susceptibility to exogenous DNA damage in COPD patients correlates with high amount of TBARS and low forced vital capacity and expiratory volume.

Conclusion: The positive correlation between increased susceptibility to exogenous DNA damage and TBARS levels in COPD patients suggests the possible involvement of oxidative stress in damage induction and/or repair inhibition.
\end{abstract}

Keywords: COPD, DNA damage, repair, comet assay, lipid peroxidation.

\section{INTRODUCTION}

Chronic Obstructive Pulmonary Disease (COPD) is a major cause of morbidity and mortality in countries with different levels of economic development, with smoking being recognized as the most important causative factor $[1,2]$. According to the World Health Organization (WHO) estimation, 80 million people in the world have moderate to severe COPD. It is estimated that in 2020 COPD will become the third leading cause of death worldwide [2].

*Address correspondence to this author at the Avenida Independência, 2293, Bloco 42, Bairro Universitário, Santa Cruz do Sul/RS- Brasil;

Tel: +55 51 37177374; Fax: +55 51 37171855; E-mail: andreag@unisc.br
COPD is currently defined as a disease preventable and treatable disease characterized by airflow limitation, resulting from an abnormal inflammatory reaction to inhaled particles (smoking) and associated with co-morbidities [2]. The pathology of COPD is multifactorial and results in significant systemic consequneces, often including systemic inflammation and oxidative stress [3,4]. The formation of reactive oxygen species (ROS) by the cigarette smoke and inflammatory cells, generated in the pulmonary epithelial tissue, has been associated with slowly progressive and irreversible decrease in forced expiratory volume in one second $\left(\mathrm{FEV}_{1}\right)$, loss of muscle mass and muscle dysfunction [4,5]. The abnormal inflammatory response that causes these pat- 
terns of injury has already to be fully characterized, and it is likely that there are multiple pathways leading to impaired lung function [5]. Cigarette smoking provides the initial stimulus, which recruits inflammatory cells into the lung parenchyma increasing the inflammatory process and probably modulating some of the systemic effects of COPD [5-7]. Additionally, there is some evidence suggesting that the DNA damage/repair imbalance may contribute to increased risk of lung carcinoma in COPD $[8,9]$.

Some of the many different compounds in cigarette smoke can react directly with cellular components to form radicals, while other procarcinogen substances must be activated to produce single- and double strand breaks into DNA $[7,10]$. However, only a small number of smokers are diagnosed with clinically relevant COPD, suggesting that COPD is the result of host-environmental interaction, most probably genetically predetermined [11]. Some studies have reported markedly increased DNA damage levels in COPD patients that correlate with the smoking status $[9,12,13]$. The cellular processes of DNA damage induction and repair are fundamental for the maintenance of genome integrity, and the modulation of these processes can dramatically increase individual susceptibility to cancer [14]. The cellular and molecular mechanisms that facilitate the progression toward the disease or its evasion are unknown [11].

Comet assay has been used in various studies to investigate the effect of ROS on DNA because it is a rapid, simple and sensitive technique for measuring DNA breaks and repair in single cells in connection with various diseases [1517]. The present study was therefore designed to assess the level of DNA damage and the susceptibility to exogenous mutagens in peripheral blood cells of COPD patients and healthy individuals, evaluated by comet assay. The oxidative stress was also evaluated by means of thiobarbituric acid reactive species (TBARS) in blood plasma.

\section{MATERIALS AND METHODOLOGY}

Fifty-one COPD patients, with a mean age of $65.33 \pm 8.91$ years, treated at Santa Cruz Hospital by the Research Group for Health Rehabilitation, Santa Cruz do Sul, RS, Brazil were included in this study. COPD was diagnosed according to the Global Initiative for Chronic Obstructive Lung Disease guidelines-GOLD [2], using clinical history, physical examination, and presence of airflow obstruction, defined as a ratio of forced expiratory volume in one second $\left(\mathrm{FEV}_{1}\right)$ to forced vital capacity (FVC) less than $70 \%$ of predicted value. The patients were grouped in relation to COPD stage as mild (8), moderate (16), severe (16) or very severe (11) and pharmacologic therapy [2]. The COPD patients were matched by gender, age and body mass index (BMI) with 51 control individuals without pulmonary disease. The study protocol was approved by the Ethics Committee of UNISC, protocol number 2011/08. All individuals answered the personal health questionnaire and signed informed consent before the interview. Peripheral blood samples were collected from patients and control individuals at rest early in the morning.

\subsection{Obtaining Sample}

The peripheral blood $(10 \mathrm{~mL})$ samples were collected early in the morning from fasted COPD patients and controls into two tubes with EDTA, being one aliquot for the comet assay and the other aliquot to obtain blood plasma.

\subsection{DNA Damage Evaluation by Comet Assay}

The comet assay was performed under alkaline and neutral conditions according to the procedure of Singh and coworkers [18,19]. Aliquots of $10 \mu \mathrm{l}$ freshly collected whole blood were mixed with $90 \mu \mathrm{l}$ low melting (LMP) agarose $(0.7 \%$ in PBS) and added to microscope slides pre-coated with $1.5 \%$ agarose. The slides were then incubated in icecold lysis solution $(2.5 \mathrm{M} \mathrm{NaCl}, 100 \mathrm{mM}$ EDTA, $10 \mathrm{mM}$ Tris, $20 \mathrm{mM} \mathrm{NaOH}, \mathrm{pH} 10.2,1 \%$ Triton X-100 and $10 \%$ DMSO). After $24 \mathrm{~h}$ at $4{ }^{\circ} \mathrm{C}$, the slides were removed from the lysis solution and placed in an electrophoresis unit filled with fresh electrophoresis buffer at $4{ }^{\circ} \mathrm{C}$. In the alkaline version of Comet assay (10 M NaOH, $1 \mathrm{mM}$ EDTA, $\mathrm{pH}>13), 20 \mathrm{~min}$ of denaturation and $15 \mathrm{~min}$ electrophoresis time were used. For the neutral condition (3 M sodium acetate, $1 \mathrm{M}$ Tris, $\mathrm{pH}=8.5$ ), the denaturation time of $1 \mathrm{~h}$ and electrophoresis time of $1 \mathrm{~h}$ were used. In both versions of the comet assay, after electrophoresis, the slides were neutralized $(0.4 \mathrm{M}$ Tris, $\mathrm{pH} 7.5$ ) and washed in water. The samples were subjected to electrophoresis at the different batches and reference standards (positive/negative controls with known levels of damage) were included in each electrophoresis run. The slides were left to dry overnight at room temperature, then fixed and stained with silver nitrate in accordance to Nadin et al. [20]. For DNA damage evaluation, 100 cells per individual (50 cells from two coded slides) were analyzed blindly under optical microscopy at $100 \times$ magnification. The cells were visually scored by measuring the DNA migration length and the amount of DNA in the tail into five classes, from undamaged -0 , to maximally damaged -4 , and a damage index (DI) value, which is an arbitrary score, was calculated for each sample [21]. International guidelines and recommendations for the comet assay consider that visual scoring of comets is a well-validated evaluation method [22,23]. Damage index thus ranged from 0 (completely undamaged: 100 cells $\times 0$ ) to 400 (with maximum damage: 100 cells $\times 4$ ).

\subsection{Comet Assay to Assess the Susceptibility to Exoge- nous DNA Damage}

For the assessment of susceptibility to exogenous DNA damage, whole blood cells were treated with methylmethane sulfonate (MMS; $8 \times 10^{-5} \mathrm{M}$ ) for $1 \mathrm{~h}$ or $3 \mathrm{~h}$ at $37^{\circ} \mathrm{C}$ prior to slide preparation, and proceeded up the steps of the alkaline comet assay as described above. The percentage of residual DNA damage after 3-h MMS treatment was calculated using the value of 1-h MMS treatment for each subject as $100 \%$.

\subsection{Lipid Peroxidation}

Lipid damages were monitored by the formation of thiobarbituric acid reactive species (TBARS) during an acidheating reaction, which has been widely adopted as a sensitive method for measuring lipid peroxidation. First, $1000 \mu \mathrm{L}$ of $5 \%$ trichloroacetic acid were added to $250 \mu \mathrm{L}$ of supernatants and centrifuged at $7000 \mathrm{~g}$ for $10 \mathrm{~min}$. Then $1000 \mu \mathrm{L}$ 
of sulfuric acid (3M) were mixed with $1000 \mu \mathrm{L}$ of thiobarbituric acid solution. The reaction mixture was incubated in a boiling water bath for 15 minutes and cooled to room temperature. Then $3500 \mu \mathrm{L}$ of n-butanol was added and centrifuged at $7000 \mathrm{~g}$ for 5 minutes. The absorbance was read at $532 \mathrm{~nm}$ [24]. Results were expressed as nmol/g of protein. Total protein levels were evaluated using the Biureto Total Proteins kit from Labtest (Labtest Diagnostica S.A., Brazil).

\subsection{Statistical Analysis}

The statistical analyses were performed using the Statistical Package SPSS 17.0 and $\mathrm{p} \leq 0.05$ was considered statistically significant. The data are expressed as mean \pm standard deviation. Categorical variables were compared using $\chi^{2}$ tests. Differences between values for control individuals and COPD patients were assessed using Mann-Whitney Test. The comparison among multiple groups was performed by one-way analysis of variance (ANOVA) with post hoc Tukey's multiple comparison test. The correlations between the parameters studied were evaluated by Spearman's test.

\section{RESULTS}

The general characteristics of COPD patients and control group are shown in Table 1. The COPD patients and matched controls were similar in terms of age, gender, ethnicity, BMI and comorbidities, but differed regarding smoking status, number of cigarettes smoked per year and smoking duration was higher in COPD patients.

Table 1. General and Clinical Characteristic in the COPD Patients and Control Group

\begin{tabular}{|c|c|c|c|}
\hline & COPD (n) & Control (n) & $p$ Value for Mann-Whitney Test \\
\hline Subjects & 51 & 51 & - \\
\hline Age (years) ${ }^{a}$ & $65.33 \pm 8.91$ & $63.61 \pm 9.40$ & $>0.05$ \\
\hline BMI $(\mathrm{kg} / \mathrm{m} 2)^{\mathrm{a}}$ & $25.75 \pm 5.71$ & $26.82 \pm 3.89$ & $>0.05$ \\
\hline Gender (male) & 30 & 28 & $>0.05$ \\
\hline Ethnicity (white) & 45 & 50 & $>0.05$ \\
\hline \multicolumn{4}{|l|}{ Smoking Status } \\
\hline Never/ Former/ Current & $5 / 34 / 12$ & $22 / 25 / 4$ & $\chi^{2} 0.000$ \\
\hline \multicolumn{4}{|l|}{ Cigarettes-year ${ }^{\mathrm{b}}$} \\
\hline Current smoking & $8059(3650-14600)$ & $7026(3650-10950)$ & $>0.05$ \\
\hline Former smoking & $10490(1095-25550)$ & $5621(1095-14600)$ & 0.003 \\
\hline \multicolumn{4}{|l|}{ Smoking Duration } \\
\hline$>30$ years & 36 & 9 & $\chi^{2} 0.000$ \\
\hline \multicolumn{4}{|l|}{ Comorbidities } \\
\hline SAH & 14 & 11 & - \\
\hline Heart disease & 9 & 2 & - \\
\hline Diabetes & 7 & 1 & - \\
\hline \multicolumn{4}{|l|}{ COPD Status ${ }^{c}$} \\
\hline Mild & 8 & - & - \\
\hline Moderate & 16 & - & - \\
\hline Severe & 16 & - & - \\
\hline Very Severe & 11 & - & - \\
\hline Pharmacologic Therapy & & - & - \\
\hline Bronchodilators & 48 & & \\
\hline Inhaled Corticosteroids & 32 & & \\
\hline Oral Cortiscoteroids & 3 & & \\
\hline Combination Therapy ${ }^{\mathrm{d}}$ & 35 & & \\
\hline
\end{tabular}

n, sample number; ${ }^{a}$ Data are presented as mean $\pm \mathrm{SD} ;{ }^{\mathrm{b}}$ Median (minimum-maximum); BMI, Body Mass Index;

SAH, Systemic Arterial Hypertension; ${ }^{\mathrm{c}}$ COPD Status by GOLD [2]; ${ }^{\mathrm{d}}$ Combination Therapy: Inhaled Corticosteriodes + Bronchodilators drugs. 
The pulmonary function and comet assay results are shown in Table 2. The damage index (DI) in the alkaline comet assay (detects single- and double-DNA strand breaks and alkali-labile sites) and in the neutral comet assay (detects double breaks) was significantly elevated in COPD patients in relation to the control group.

The susceptibility to MMS-induced $\left(8 \times 10^{-5} \mathrm{M}\right)$ DNA damage was measured after 1 -h or 3 -h of treatment. As shown in Fig. (1), the DNA damage index in the control group increased after $1 \mathrm{~h}$ of MMS treatment, and slightly decreased after $3 \mathrm{~h}$, whereas DNA damage in COPD patients remained elevated following 3-h MMS treatment. To investigate these differences, we calculated the changes in DI after 3-h treatment in relation to the 1-h DI value for each person. This parameter, called residual DNA damage, showed that the DNA damage detected after 3-h treatment in controls decreased in relation to the 1-h value (Fig. 2), which could indicate repair process initiation. In contrast, the residual DNA damage in patients further increased, indicating higher susceptibility to alkylation damage.

The DNA damage index was compared between patients grouped according to the COPD severity as defined by GOLD [2] (Fig. 3) and corticosteroids drugs currently (Fig. 4). The values of DNA damage after 3-h MMS treatment for patients with moderate, severe and very severe COPD were significantly higher than in the control group. However, no difference was observed between the different groups of patients with COPD.

The mean DI in patients treated with corticosteroids, which decrease the inflammation process, was also slightly lower (Fig. 4).

Table 3 shows the correlations between the parameters studied in patients and controls. In COPD patients, the basal DNA damage in comet assay correlated negatively with TBARS and the percentage of residual damage, in contrast to the control individuals that presented a positive correlation. Disease indicators $\mathrm{FEV}_{1}$ and FVC correlated negatively with the percentage of residual DNA damage, suggesting that patients with more severe COPD presented higher increment in DNA damage following 3-h MMS treatment. The basal DI in the alkaline and neutral comet assay in COPD patients

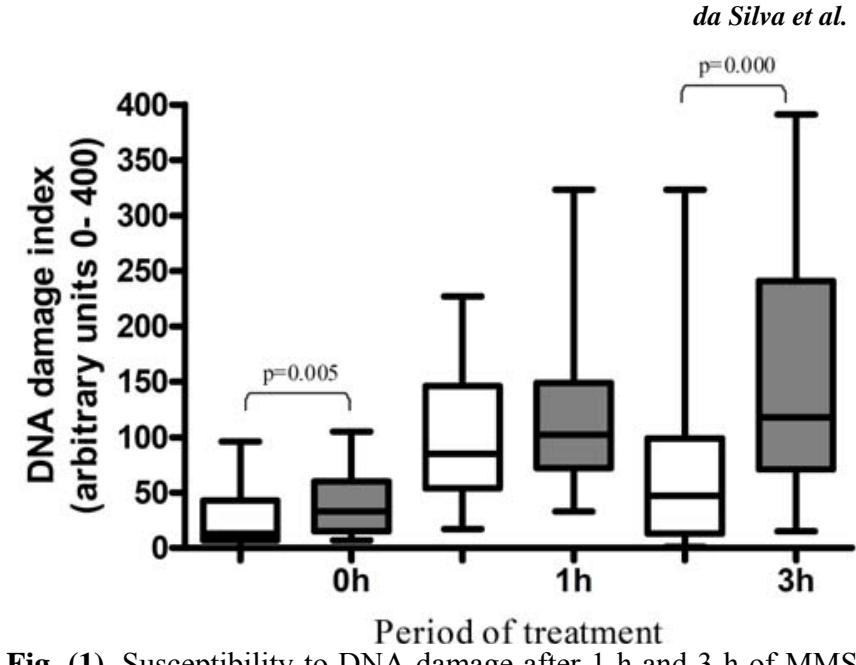

Fig. (1). Susceptibility to DNA damage after 1-h and 3-h of MMS $(8 \times 10-5 \mathrm{M})$ treatment in blood of COPD patients and healthy controls. Baseline damage $(0 \mathrm{~h})$ in blood samples was estimated by means of alkaline comet assay without MMS. Data are presented as mean \pm SD, controls - white bars, patients - gray bars. Statistical analysis was performed by one-way ANOVA with Tukey's multiple comparison test.

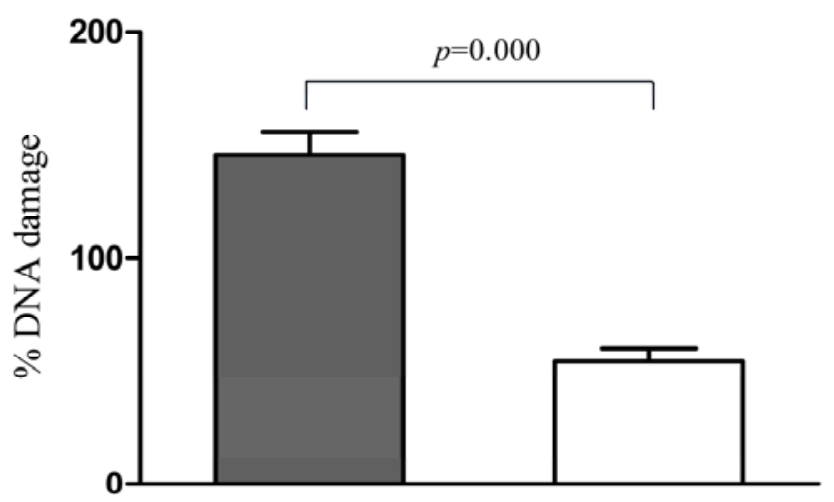

Fig. (2). Residual DNA damage in blood cells of COPD patients and healthy controls following 3-h MMS treatment. The percentage of residual DNA damage after 3-h MMS treatment was calculated taking the value of $1-\mathrm{h}$ MMS treatment for each subject as $100 \%$. Data are presented as mean $\pm \mathrm{SD}$; controls - white bars, patientsblack bars. Statistical analysis was performed by Mann- Whitney U-test.

Table 2. Pulmonary Function, Biochemical Parameters and Comet Assay Results in the COPD Patients and Control Group

\begin{tabular}{|l|c|c|c|}
\hline \multicolumn{1}{|c|}{ Characteristics } & COPD (n=51) & Control (n=51) & p Mann-Whitney \\
\hline \hline FEV $_{1}$ (\% predicted) & $42.90 \pm 19.03$ & $86.14 \pm 11.72$ & 0.000 \\
\hline FVC (\% predicted) & $62.20 \pm 18.28$ & $90.75 \pm 13.67$ & 0.000 \\
\hline FEV $_{1} /$ FVC (\% predicted) & $67.92 \pm 19.58$ & $105.24 \pm 70.28$ & 0.000 \\
\hline TBARS (nmol/mg of protein) & $10.41 \pm 5.01$ & $9.16 \pm 4.26$ & 0.005 \\
\hline $\begin{array}{l}\text { Damage Index - } \\
\text { Alkaline Comet Assay }\end{array}$ & $36.71 \pm 25.41$ & $26.65 \pm 27.96$ & 0.05 \\
\hline $\begin{array}{l}\text { Damage Index - } \\
\text { Neutral Comet Assay }\end{array}$ & $47.53 \pm 32.45$ & $37.49 \pm 38.05$ & \\
\hline
\end{tabular}

Data are presented as mean $\pm \mathrm{SD} ; \mathrm{FEV}_{1}$, forced expiratory volume in one second; $\mathrm{FVC}$,

forced vital capacity; ${ }^{\text {a }}$ Data for 49 COPD patients and 50 controls. 

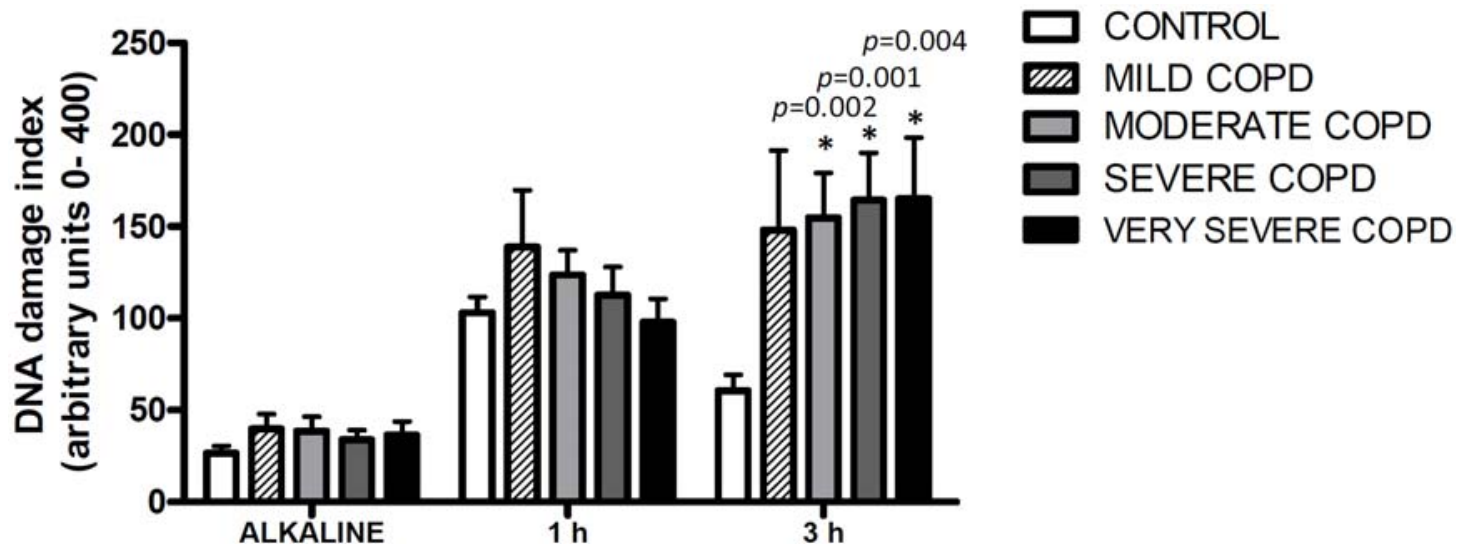

Fig. (3). DNA damage index in alkaline Comet assay after 1-h or 3-h MMS treatment in patients grouped according to the COPD severity. Data are presented as mean $\pm \mathrm{SD}$. Statistical analysis was performed by one-way ANOVA with Tukey's multiple comparison test.

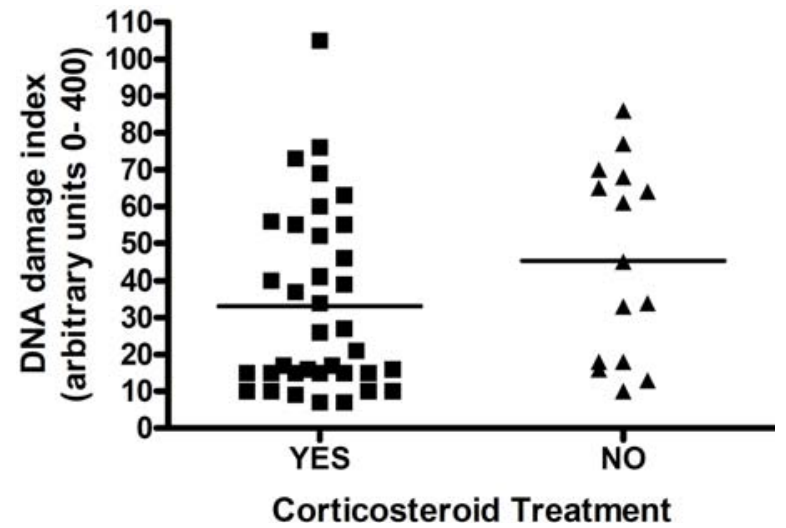

Fig. (4). Damage Index in alkaline Comet assay in blood of COPD patients treated or not with corticosteroids. Statistical analysis was performed by Mann-Whitney Test, $\mathrm{p}=0.077$.

correlated positively with FVC, suggesting that patients with severe and very severe COPD presented lower basal damage. Moreover, the DI after 3-h MMS treatment in patients correlated positively with TBARS, indicating that the enhanced susceptibility and/or repair inhibition could be related to oxidative stress.

In the control group, $\mathrm{FEV}_{1}$ correlated negatively with DI (alkaline and neutral Comet assay) and the susceptibility to DNA damage induction (1-h MMS treatment) correlated positively with smoking (cigarettes-year). Moreover, the percentage of residual damage correlated negatively with the smoking cessation time.

\section{DISCUSSION}

Oxidative damage to DNA can have a great impact on human health, considering the growing recognition that such damage may both initiate and promote carcinogenesis. The pathogenesis of COPD leads to an increase in the oxidative burst in lungs and evidence suggests that this increase is implicated in pathogenic processes, such as damage to pulmonary cells, mucus hypersecretion, antiprotease inactivation and exacerbation of lung inflammation [2]. Recently, it has been suggested that the oxidative stress may extend beyond the lung to generate the systemic manifestation of COPD [13]. Our results, detecting increased DNA damage in COPD patients (Table 2), are in agreement with those by
Ceylan et al. [12], who observed through the alkaline comet assay markedly increased levels of oxidative stress and DNA damage in peripheral blood cells of such patients. The authors have also found that the increase in DNA damage correlates with the use of biomass fuel for cooking and the smoking status. However, in our study, correlation between DNA damage with number of cigarettes smoked per year and smoking cessation time was observed only in the control group (Table 3). The studies about smoker-induced DNA damage are contradictory and show that there is no difference between smokers and nonsmokers $[25,26]$. Others studies report unexpected negative results [27] and sometime smokers present lower DNA damage than non- smokers [28]. A few cigarettes per day may stimulate an adaptive response and a continued exposure to mutagens/carcinogens may induce resistance to further DNA damage [29]. More important is the cumulative smoking exposure [25] so we stratified our sample in heavy smokers (i.e $\geq 30$ cigarettes per day) e light smokers (i.e $<30$ cigarettes per day) e non-smokers. Our results were equal to literature no significant difference was found among heavy smokers, only between nonsmokers and light smokers (i.e COPD showed higher DNA damage).

The relatively high basal DNA damage detected in our study for both patients and controls, which can be attributed to advanced age, presence of comorbidities in both groups, and current use of antihypertensive drugs. The high standard 
Table 3. Correlations between the Parameters Analyzed in Patients and Controls

\begin{tabular}{|c|c|c|c|c|}
\hline Parameters & \multicolumn{2}{|c|}{ COPD } & \multicolumn{2}{|c|}{ CONTROLS } \\
\hline FVC- basal DI in alkaline comet assay & 0.386 & 0.005 & & \\
\hline DI following $3 \mathrm{~h}$ MMS treatment - TBARS & 0.329 & 0.021 & & \\
\hline$\%$ Residual damage- basal DI in alkaline comet assay & -0.324 & 0.020 & & \\
\hline$\%$ Residual damage- $\mathrm{FEV}_{1}$ & -0.279 & 0.047 & & \\
\hline$\%$ Residual damage- FVC & -0.301 & 0.032 & & \\
\hline $\mathrm{FEV}_{1}$ - basal DI in neutral comet assay & & & -0.296 & 0.035 \\
\hline TBARS- basal DI in neutral comet assay & & & 0.292 & 0.039 \\
\hline$\%$ Residual damage- basal DI in alkaline comet assay & & & 0.413 & 0.003 \\
\hline$\%$ Residual damage- smoking cessation time & & & -0.405 & 0.045 \\
\hline
\end{tabular}

$\mathrm{FEV}_{1}$, forced expiratory volume in one second; FVC, forced vital capacity; DI - damage index; \% Residual damage - calculated for DI after 3h MMS treatment for each subject taking the value of DI after $1 \mathrm{~h}$ MMS treatment as $100 \%$.

deviations for the DNA damage values in the comet assay found could reflect the great genetic heterogeneity of the groups. It is a critical aspect in human biomonitoring studies associated to physiological state and life style [13]. DNA damage and DNA repair seem to be closely associated with aging as a result of endogenous factors, lifestyle, occupational or environmental exposure [30]. Some atherosclerosisrelated diseases, whose pathogenesis involves both inflammation and oxidative stress, lead to DNA-damage induction [31] and could explain the higher basal DNA damage found in our study in patients and in matched controls [32].

In our study, an enhanced susceptibility to the alkylating agent MMS that induced DNA damage was observed in COPD patients (Fig. 1), especially in moderate, severe and very severe COPD (Fig. 3). The residual DNA damage caused by MMS treatment further increased in COPD patients, indicating the induction of persistent DNA damage, which could reflect DNA repair inhibition (Fig. 2). In the control group the induced DNA damage was transient probably due to induction of DNA repair mechanism.

Furthermore, the DI after 3-h MMS treatment positively correlates with the amount of TBARS in COPD patients, indicating that increased oxidative damage could be responsible for the elevated susceptibility to exogenous DNA damage. On the other hand, the increased DI could result from DNA damage accumulation as a result of delayed DNA repair process. Moreover, the observed negative correlation between the percentage of residual damage and basal DNA damage in patients (i.e. higher susceptibility to exogenous DNA damage, correlated with lower basal damage), which contrasts with the positive one observed in controls, could be attributed to DNA metabolism inhibition at toxic conditions.
As the comet assay, in addition to the direct strand breaks in DNA, also detects strand breaks formed as intermediates during the DNA repair process, low basal DNA damage could indicate cell toxicity (i.e. chronic oxidative stress), leading to decrease in genotoxicity. Such a decrease in basal DNA damage in lymphocytes of patients with breast cancer (lower than in controls) was associated with repair inhibition and possible elimination of highly damaged cells by apoptosis [14]. It is important to point out that an increased apoptosis in COPD patients has been reported, which persists even after smoking cessation [33-35]. The reduced repair capacity among cancer patients and their relatives shows that such capacity can be genetically determined [36,37]. Moreover, cancer patients treated with irradiation only those with DNA repair defect developing secondary thyroid tumors [38]. Alternatively, DNA repair inhibition can be attributed to modulated repair signaling and/or inactivation of repair enzymes as a result of altered intracellular redox status by persistent inflammatory processes $[9,14]$.

Inhaled corticosteroids are frequently used in moderate to severe COPD, in order to interrupt the inflammatory pathways and have shown to decrease the number of exacerbations and improve quality of life $[2,39]$. Glucocorticosteroids may have direct effects on oxidative stress by decreasing the number and/or activity of cells involved in ROS production such as the number of neutrophils in COPD [40]. On the other hand, it has been shown that the administration of inhaled or intravenous corticosteroids in stabile COPD patient can suppress the ROS generation during treatment and decrease the DNA damage $[41,42]$. Our results also showed a decrease, although not significant, in the basal DNA damage in patients treated with corticosteroids (Fig. 4). 
In conclusion, our results showed that COPD patients presented significantly elevated basal DNA damage in peripheral blood cells, as detected by the comet assay, in relation to the control group. COPD patients were also more susceptible to exogenous DNA damage induction by MMS treatment. Moreover, the increased susceptibility in these patients positively correlated with the amount of TBARS suggesting the involvement of altered redox balance in the DNA damage accumulation, and probably in the etiology and pathogenesis of COPD. The evaluation of susceptibility to exogenous genotoxic agents in COPD patients, as detected by comet assay, could be useful as biomarker of the disease progression, considering the correlation found between this parameter and $\mathrm{FVC}$ and $\mathrm{FEV}_{1}$.

\section{CONFLICT OF INTEREST}

The authors confirm that this article content has no conflicts of interest.

\section{SUPPORT}

PRONEX-FAPERGS/CNPq number 10/0044-3, Santa Cruz Hospital and Research Group Health Rehabilitation and its Interfaces, University of Santa Cruz do Sul - UNISC, Federal University of Rio Grande do Sul - UFRGS.

\section{ACKNOWLEDGEMENTS}

The authors would like to thank all volunteers who participated in this study and the Biotechnology and Genetics Laboratory - UNISC. This work was supported by the Brazilian Agencies: Fundação de Amparo à Pesquisa do Estado do Rio Grande do Sul (FAPERGS) and Conselho Nacional de Desenvolvimento Científico e Tecnológico (CNPq).

\section{REFERENCES}

[1] Laniado-Laborín R. Smoking and chronic obstructive pulmonary disease (COPD). Parallel Epidemics of the 21st Century. Int J Environ Res Public Health 2009; 6: 209-24.

[2] Global Strategy for the Diagnosis, Management and Prevention of COPD. Global initiative for chronic obstructive lung disease (GOLD) 2010

[3] Tzortzaki EG, Dimakou K, Neofytou E, et al. Oxidative DNA Damage and Somatic Mutations. Chest 2012; 141(5): 1243-50.

[4] Verhage TL, Heijdra YF, Molema J, Daudey L, Dekhuijzen R. Vercoulen JH. Adequate Patient Characterization in COPD: Reasons to Go Beyond GOLD Classification. Open Respir Med J 2009; 3:1-9.

[5] Gladysheva ES, Malhotra A. Owens RL. Influencing the decline of lung function in COPD: use of pharmacotherapy. Int J Chron Obstruct Pulmon Dis 2010; 5:153-64.

[6] Chung KF, Marwick JA. Molecular mechanisms of oxidative stress in airways and lungs with reference to asthma and chronic obstructive pulmonary disease. Ann N Y Acad Sci 2010; 1203:85-91.

[7] Hoffmann H, Isner C, Högel J, Speit G. Genetic polymorphisms and the effect of cigarette smoking in the comet assay. Mutagenesis 2005; 5: 359-64.

[8] Caramori G, Adcock IM, Casolari P. Unbalanced oxidant-induced DNA damage and repair in COPD: a link towards lung cancer. Thorax 2011; 66:521-7.

[9] Repine JE. Bast A. Lankhorst I. Oxidative stress in chronic obstructive pulmonary disease. Oxidative Stress Study Group. Am J Respir Crit Care Med 1997; 156: 341-57.

[10] Koshiol J, Rotunno M, Consonni D, et al. Chronic obstructive pulmonary disease and altered risk of lung cancer in a populationbased case-control study. PLoS ONE 2009; 4: 7380.
[11] Tonello A, Poli G. Rethinking chronic obstructive pulmonary disease. Med Hypotheses 2011; 76:358-60.

[12] Ceylan E, Kocyigit A, Gencer M, Aksoy N, Selek S. Increased DNA damage in patients with chronic obstructive pulmonary disease who had once smoked or been exposed to biomass. Respir Med 2006; 100:1270-6.

[13] Maluf SW, Mergener M, Dalcanale L, et al. DNA damage in peripheral blood of patients with chronic obstructive pulmonary disease (COPD). Mutat Res 2007; 626:180-4.

[14] Agnoletto, MH, Guecheva TN, Dondé F, et al. Association of low repair efficiency with high hormone receptors expression and SOD activity in breast cancer patients. Clin Biochem 2007; 40:1252-8.

[15] Collins AR, Harrington V. Repair of oxidative DNA damage: assessing its contribution to cancer prevention. Mutagenesis 2002; 17: 489-93.

[16] Blasiak J, Arabski M, Krupa R, et al. Basal, oxidative and alkylative DNA damage, DNA repair efficacy and mutagen sensitivity in breast cancer. Mutat Res 2004; 554: 39-148.

[17] Mutlu-Türkoðlu Ü, Akalýn Z, Ýlhan E, et al. Increased plasma malondialdehyde and protein carbonyl levels and lymphocyte DNA damage in patients with angiographically defined coronary artery disease. Clin Biochem 2005; 38:1059-65.

[18] Singh NP, McCoy T, Tice RR, Schneider EL. A simple technique for of low levels of DNA damage in individual cells. Exp Cell Res 1988; 175: 184-91.

[19] McKenna DJ, McKeown SR, McKelwey-Martin VJ. Potential use of the comet assay in the clinical management of cancer. Mutagenesis 2008; 3: 183-90.

[20] Nadin, SB, Vargas-Roig, LM, Ciocca, D. A silver staining method for single-cell gel assay. J Histochem Cytochem 2001; 49:1183-6.

[21] Maluf SW, Erdtmann B. Follow-up study of genetic damage in lymphocytes of pharmacists and nurses handling antineoplastic drugs evaluated by cytokinesis-block micronuclei analysis and single cell gel electrophoresis assay. Mutat Res 2000; 471:21-7.

[22] Tice RR, Agurell E, Anderson, D. et al. Single cell gel/comet assay: guidelines for in vitro and in vivo genetic toxicology testing. Environ Mol Mutagen 2000; 35: 206-21.

[23] Collins AR. Oscoz AA. Brunborg G. et al. The comet assay: topical issues. Mutagenesis 2008; 23(3):143-51.

[24] Wills ED. Mechanism of lipid peroxidation formation in animal tissues. Biochem J 1966; 3: 667-76.

[25] Casella M, Miniati M, Monti S, Minichilli F, Bianchi F, Simi S. No evidence of chromosome damage in chronic obstructive pulmonary disease (COPD). Mutagenesis 2006; 21(2):167-71.

[26] DeMarini DM. Genotoxicity of tobacco smoke and tobacco smoke condensate: a review. Mutat Res 2004; 567(2-3):447-74.

[27] Speit G, Witton-Davies T. Heepchantree W. et al. Investigations on the effect of cigarette smoking in the comet assay. Mutat Res 2003; 542(1-2): 33-42.

[28] Barale R, Chelotti L, Davini T, et al. Sister chromatid exchange and micronucleus frequency in human lymphocytes of 1,650 subjects in an Italian population: II. Contribution of sex, age, and lifestyle. Environ Mol Mutagen 1998; 31(3): 228-42.

[29] Bonassi S, Neri M, Lando C, et al. Effect of smoking habit on the frequency of micronuclei in human lymphocytes: results from the Human MicroNucleus project. Mutat Res 2003; 543(2): 155-66.

[30] Mergener M, Martins MR, Antunes MV, et al. Oxidative stress and DNA damage in older adults that do exercises regularly. Clin Biochem 2009; 42: 1648-53.

[31] Zhou F, Onizawa S, Nagai A, Aoshiba K. Epithelial cell senescence impairs repair process and exacerbates inflammation after airway injury. Respir Res 2011; 12: 78.

[32] Subash, P, Premagurumurthy K, Sarasabharathi A, Cherian KM. Total antioxidant status and oxidative DNA damage in South Indian population of essential hypertensives. J Hum Hypertens 2010; 24: 475-82.

[33] Demedts IK, Demoor T, Bracke KR, Joos GF, Brusselle GG. Role of apoptosis in the pathogenesis of COPD and pulmonary emphysema. Respir Res 2006; 7-53.

[34] Adcock IM, Caramori G, Barnes PJ. Chronic Obstructive Pulmonary Disease and Lung Cancer: New Molecular Insights. Respiration 2011; 81: 265-84.

[35] Rennard SI, Togo S, Holz O. Cigarette Smoke Inhibits Alveolar Repair A Mechanism for the Development of Emphysema. Proc Am Thorac Soc 2006; 3: 703-8. 
[36] Rajaee-Behbahani N, Schmezer P, Risch A, et al. Altered DNA repair capacity and bleomycin sensitivity as risk markers for nonsmall cell lung cancer. Int J Cancer 2001; 95:86-91.

[37] Gackowski D, Kowalewski J, Siomek A, Olinski R. Oxidative DNA damage and antioxidant vitamin level: comparison among lung cancer patients, healthy smokers and nonsmokers. Int J Cancer 2005; 114:153-6.

[38] Leprat F, Alapetite C, Rosselli F, et al. Impaired DNA repair as assessed by the comet assay in patients with thyroid tumors after a history of radiation therapy: a preliminary study. Int J Radiat Oncol Biol Phys 1998; 40(5): 1019-26.
[39] Tonello A, Poli G. Rethinking chronic obstructive pulmonary disease. Med Hypotheses 2011; 76:358-60.

[40] Sadowska AM, Klebe B, Germonpré P, Backer WA. Glucocorticosteroids as antioxidants in treatment of asthma and COPD New application for an old medication? Steroids 2007; 72: 1-6.

[41] Antoniu SA. Effects of inhaled therapy on biomarkers of systemic inflammation in stable chronic obstructive pulmonary disease. Biomarkers 2010; 15: 97-103.

[42] Stolarek R, Bialasiewicz P, Krol M, Nowak D. Breath analysis of hydrogen peroxide as a diagnostic tool. Clin Chim Acta 2010; 14: 1849-61.

Received: June 12, 2012

Revised: August 23, 2012

Accepted: August 28, 2012

(C) da Silva et al.; Licensee Bentham Open.

This is an open access article licensed under the terms of the Creative Commons Attribution Non-Commercial License (http://creativecommons.org/licenses/by-nc/3.0/) which permits unrestricted, non-commercial use, distribution and reproduction in any medium, provided the work is properly cited. 